\title{
Semen quality of men employed at a lead smelter
}

Bruce H Alexander, Harvey Checkoway, Chris van Netten, Charles H Muller, Timothy G Ewers, Joel D Kaufman, Beth A Mueller, Thomas L Vaughan, Elaine M Faustman

\begin{abstract}
Objective-To evaluate the effects of recent and long term occupational lead exposure on indicators of male reproductive health.

Methods-In a cross sectional study of male employees of a lead smelter ( $n=$ 2469), blood samples were obtained from 152 workers including 119 who also provided semen samples. Semen analysis and serum concentrations of testosterone, follicle stimulating hormone, and luteinising hormone were used as indicators of reproductive health. Semen and hormone variables were examined in relation to measures of current and long term body lead burden estimated from current blood lead concentrations and historical blood lead monitoring data.
\end{abstract}

Results-For current blood lead concentration groups of $<15,15-24,25-39$, $>40$ $\mu \mathrm{g} / \mathrm{dl}$, the geometric mean sperm concentrations were, respectively, 79.1, 56.5, $62 \cdot 7$, and 44.4 million cells $/ \mathrm{ml}$ and geometric mean total sperm counts were 186, 153, 137, and 89 million cells ( $P$ for trend 0.04). Compared with workers with blood lead concentrations less than $15 \mu \mathrm{g} / \mathrm{dl}$, workers with current blood lead concentrations of $40 \mu \mathrm{g} / \mathrm{dl}$ or more had an increased risk of below normal sperm concentration (odds ratio (OR) $8 \cdot 2,95 \%$ confidence interval $(95 \% \mathrm{CI}) 1 \cdot 2-57 \cdot 9)$ and total sperm count (OR 2.6, 95\% CI 0.4-15.7), based on World Health Organisation standards. Independent of current lead exposure, sperm concentration, total sperm count, and total motile sperm count were inversely related to measures of long term lead exposure. No association was found between lead exposure and measures of sperm motility, sperm morphology, or serum concentrations of reproductive hormones.

Conclusions-Blood lead concentrations below the currently accepted worker protection criteria seem to adversely affect spermatogenesis.

(Occup Environ Med 1996;53:411-416)

Keywords: lead; reproductive health; semen quality

Injury to the male and female reproductive systems is a recognised consequence of lead poisoning. ${ }^{12}$ It is unclear, however, whether blood lead concentrations below current regu- latory thresholds harm the reproductive system. The United States Occupational Safety and Health Administration ${ }^{3}$ requires that a person with a single blood lead measurement of $60 \mu \mathrm{g} / \mathrm{dl}$ or greater, or periodic measurements over $50 \mu \mathrm{g} / \mathrm{dl}$ leaves work on medical grounds. Whether these standards adequately protect reproductive health has implications for workers in occupations where lead exposure is common. ${ }^{4}$

Lead has been linked to damage or dysfunction of the male reproductive system in both animal $^{5}$ and human studies. ${ }^{5-15}$ Occupational exposure to lead has been associated with impaired semen quality, ${ }^{8-11}$ an increased frequency of spontaneous abortion and other adverse outcomes of pregnancies fathered by workers exposed to lead, ${ }^{12-14}$ and possible decreases in fertility rates. ${ }^{15}$ Plausible mechanisms for impaired spermatogenesis are a direct effect on testicular function or an effect mediated by hormonal imbalances. ${ }^{7} 9^{16-18}$ The scientific literature associating occupational lead exposure with impaired reproductive health in men primarily consists of studies involving populations with blood lead concentrations in excess of $60 \mu \mathrm{g} / \mathrm{dl} .^{8-10}$ Furthermore, no information is available on the effects of long term exposure to lead on male reproductive health.

This study was conducted to examine the effects of current and long term occupational lead exposures on semen quality and reproductive hormone concentrations.

\section{Material and methods \\ STUDY SETTING}

The study was conducted in June and July, 1993 at the Cominco smelter in Trail, British Columbia. Smelting of lead ores began in 1899 and primarily produces lead and zinc. Modifications of the smelting and refining processes, environmental controls, and the use of personal protective equipment have reduced exposure of the workers over time, but the potential for excessive exposure still exists. Individual blood lead concentrations as high as 90,85 , and $79 \mu \mathrm{g} / \mathrm{dl}$ were recorded in the workforce in 1970, 1980, and 1990, respectively. The mean blood lead concentrations from a sample of monitored workers were 42,41 , and $38 \mu \mathrm{g} / \mathrm{dl}$, respectively.

\section{STUDY DESIGN}

The study was a cross sectional survey comparing variables of semen quality and concentrations of reproductive hormones in serum 
among men employed at the smelter. All male workers employed on 1 May, 1993 ( $\mathrm{n}=$ 2123) and workers laid off in the preceding year $(n=346)$ were recruited by postal questionnaire. To encourage participation the study was discussed in meetings with small groups of workers, and a follow up postcard and two repeated mailings of the questionnaire were sent to non-responders. The questionnaire asked for data on reproductive history, sociodemographic characteristics, and personal habits, such as tobacco and alcohol use, and invited workers to donate blood and semen samples.

\section{SAMPLE COLLECTION AND ANALYSIS}

A field laboratory was established in the nurse's station at the smelter. Informed consent forms, previously approved by the University of Washington Human Subjects Committee, describing study purposes, risks, and benefits, were given to participants. Semen sample donors were provided with sample collection containers, instructions on sample collection and transport, and a brief questionnaire to record information pertaining to the analysis of the semen sample, including time of collection, if any sample was spilled, period of abstinence from ejaculation, history of reproductive tract infections, fevers, and use of hot tubs and saunas in the previous three months. Participants were requested to abstain from ejaculation for 48 hours before the sample collection. Semen samples were collected at home or on site, delivered to the field laboratory within one hour of collection, and incubated at $37^{\circ} \mathrm{C}$ until liquification was complete. Complete semen analysis, including sperm concentration, total sperm count, percentage motility, and percentage rapid and linear motility, was completed within one hour of sample collection according to the World Health Organisation (WHO) protocol. ${ }^{19}$ Semen smears were made and later stained with Bryan-Leishman stain for assessment by one trained technician of sperm morphology with the strict morphology criteria described by Kruger et al. ${ }^{20}$

Computer assisted sperm analysis techniques $^{21}$ were used to relate measures of lead exposure to objective measures of the motility characteristics of motile sperm in semen. With phase contrast videomicrography the images of at least 100 motile sperm were recorded and subsequently analysed with a HamiltonThorne IVOS analyser, software version $10-\mathrm{H}$, at 60 frames per second. The temperature of the slide and sample was maintained at $37^{\circ} \mathrm{C}$ during the recording process. The mean values for measures of sperm motility, ${ }^{21}$ the velocity of the average path $(\mu \mathrm{m} / \mathrm{s})$, the straight line velocity $(\mu \mathrm{m} / \mathrm{s})$, the curvilinear velocity $(\mu \mathrm{m} / \mathrm{s})$, the amplitude of lateral head deflection $(\mu \mathrm{m})$, and percentage linearity (straight line velocity/curvilinear velocity) were computed for each man as an estimate of the motility characteristics of the motile sperm (velocity of average path $>5 \mu \mathrm{m} / \mathrm{s}$ ) in the sample.

Two venous blood samples were drawn by the company occupational health nurse. One sample was collected in an EDTA coated tube and refrigerated until analysed for blood lead with graphite furnace atomic absorption spectrophotometry. ${ }^{22}$ Serum was collected from the second sample for measurement of concentrations of testosterone, follicle stimulating hormone $(\mathrm{FSH})$, and luteinising hormone (LH) by radioimmunoassay. ${ }^{23}$ Serum samples were stored at $-20^{\circ} \mathrm{C}$ in the field and at $-80^{\circ} \mathrm{C}$ thereafter. Aliquots of blood were frozen for analysis of other metals potentially toxic to the male reproductive system that may exist in the smelter environment, including zinc, cadmium, arsenic, and copper, by inductively coupled plasma mass spectrometry (ICP-MS).

Current lead burden was estimated from the measured blood lead concentrations. Information on past lead exposure was obtained from company work history and blood lead monitoring records for all study participants. The lead biomonitoring programme has relied on blood lead surveillance since 1980. This programme targets workers in the highest lead exposure areas, but reaches all work areas at the smelter. Each worker's mean blood lead concentration during the 10 years preceding the study was used as the primary index of long term lead exposure. Peak blood lead concentrations during the preceding 10 years and cumulative years of employment in the highest lead exposure jobs were also evaluated as measures of long term lead exposure. Summarised work history and blood lead monitoring data were available for all actively employed workers and were used to compare study participants with all employees of the smelter.

\section{DATA ANALYSIS}

The study participants were divided into four blood lead concentration categories, <15, $15-24,25-39, \geqslant 40 \mu \mathrm{g} / \mathrm{dl}$, for both current and long term blood lead concentrations. The standard semen quality values did not follow a normal distribution and had increasing variability at the higher exposure concentrations. To describe these distributions and their relative variation, geometric means and geometric SDs were calculated for each of the blood lead concentration groups. A least squares regression model was fitted to the natural logarithm of each semen quality variable to analyse linear trends with current and long term blood lead concentrations. ${ }^{24}$ Covariates evaluated in these models were age, alcohol consumption, smoking, the presence of other metals in the blood, and abstinence before sample collection.

The prevalence of below normal values for each semen quality variable was determined by the WHO standard values ${ }^{19}$ for evaluation of infertility. Prevalence odds ratios (OR) and associated $95 \%$ confidence intervals (95\% CIs ${ }^{25}$ were calculated to estimate the risk of having a below normal value for each semen variable. The importance of potentially confounding variables, including age, smoking, alcohol consumption, the concentrations of other metals in the blood, and abstinence before sample collection were evaluated with 
Table 1 Employment and demographic characteristics of eligible study participants and all workers employed at the beginning of the study

\begin{tabular}{|c|c|c|c|c|}
\hline & \multicolumn{3}{|c|}{ Study participants } & \multirow{3}{*}{$\begin{array}{l}\text { All current } \\
\text { Employees }\end{array}$} \\
\hline & \multirow{2}{*}{$\begin{array}{l}\text { Semen } \\
\text { Donors }\end{array}$} & \multicolumn{2}{|c|}{ Non-semen donors } & \\
\hline & & All & Non-vasectomised & \\
\hline $\begin{array}{l}\text { Number } \\
\text { Age (mean) }\end{array}$ & $\begin{array}{l}119 \\
39 \cdot 7\end{array}$ & $\begin{array}{l}810 \\
42 \cdot 2\end{array}$ & $\begin{array}{l}466 \\
42 \cdot 2\end{array}$ & $\begin{array}{l}2121 \\
42 \cdot 3\end{array}$ \\
\hline \multirow{2}{*}{\multicolumn{5}{|c|}{$\begin{array}{l}\text { Blood lead concentration } \dagger \\
(\mu \mathrm{g} / \mathrm{dl}, \text { mean })\end{array}$}} \\
\hline & $28 \cdot 7$ & $28 \cdot 3$ & $27 \cdot 4$ & $28 \cdot 7$ \\
\hline \multicolumn{5}{|l|}{ Current work area (\%): } \\
\hline Lead smelter & $27 \cdot 7$ & $18 \cdot 5$ & $16 \cdot 1$ & $22 \cdot 9$ \\
\hline Refinery & $14 \cdot 3$ & $7 \cdot 7$ & $7 \cdot 7$ & $7 \cdot 7$ \\
\hline Maintenance and support & $14 \cdot 3$ & $17 \cdot 9$ & $18 \cdot 2$ & $14 \cdot 4$ \\
\hline Zinc production & $17 \cdot 6$ & $22 \cdot 0$ & $21 \cdot 5$ & $24 \cdot 0$ \\
\hline Administration or technical & $16 \cdot 8$ & $13 \cdot 9$ & $15 \cdot 5$ & $13 \cdot 8$ \\
\hline Other & $7 \cdot 5$ & $20 \cdot 0$ & $21 \cdot 0$ & $17 \cdot 2$ \\
\hline Years at smelter (mean) & $17 \cdot 0$ & $18 \cdot 5$ & $18 \cdot 2$ & $\ddagger$ \\
\hline \multicolumn{5}{|l|}{ Marital status (\%): } \\
\hline Single (never married) & $5 \cdot 0$ & $6 \cdot 4$ & $9 \cdot 9$ & \\
\hline Ever married & $92 \cdot 5$ & $93 \cdot 1$ & $89 \cdot 9$ & \\
\hline Did not respond & $2 \cdot 5$ & 0.5 & 0.2 & \\
\hline \multicolumn{4}{|l|}{ Current smokers (\%): } & $\ddagger$ \\
\hline Yes & $13 \cdot 4$ & $23 \cdot 0$ & $25 \cdot 4$ & \\
\hline $\begin{aligned} & \text { Did not respond } \\
\geqslant & 10 \text { Alcoholic beverages }\end{aligned}$ & $37 \cdot 8$ & $30 \cdot 0$ & $28 \cdot 5$ & \\
\hline a week $(\%)$ & $17 \cdot 6$ & $19 \cdot 3$ & $18 \cdot 6$ & $\ddagger$ \\
\hline Want children in the future (\%) & $19 \cdot 3$ & $7 \cdot 9$ & $12 \cdot 9$ & $\ddagger$ \\
\hline \multicolumn{5}{|l|}{ No pregnancy after trying for } \\
\hline$\geqslant 1 y(\%) \int$ & $16 \cdot 7$ & $11 \cdot 2$ & $12 \cdot 9$ & $\ddagger$ \\
\hline Sought fertility consultation (\%) $\int$ & $10 \cdot 2$ & $9 \cdot 7$ & $11 \cdot 7$ & $\ddagger$ \\
\hline
\end{tabular}

* Summarised records were available for 2121 of 2123 current employees.

tIncludes only blood lead concentrations from workers included in the blood lead monitoring system in 1993 before the study.

system in 1993

§Ever married men.

Table 2 Characteristics of workers who donated semen samples by current blood lead concentration

\begin{tabular}{|c|c|c|c|c|}
\hline & \multicolumn{4}{|c|}{ Blood lead concentration ( $\mu g / d l)$} \\
\hline & $<15$ & $15-24$ & $25-39$ & $\geqslant 40$ \\
\hline Number & 32 & 46 & 29 & 12 \\
\hline Blood lead ${ }^{\star}(\mu \mathrm{g} / \mathrm{dl}$, mean $)$ & $10 \cdot 2$ & $19 \cdot 2$ & $30 \cdot 6$ & $47 \cdot 3$ \\
\hline Age (mean) & $41 \cdot \overline{4}$ & $38 \cdot \overline{2}$ & $40 \cdot 7$ & $41 \cdot 8$ \\
\hline Years of service (mean) & $16 \cdot 4$ & $15 \cdot \overline{7}$ & $18 \cdot 4$ & $19 \cdot 8$ \\
\hline \multicolumn{5}{|l|}{ Current smokers $(\%)$ : } \\
\hline Yes & $12 \cdot 5$ & $13 \cdot 0$ & 6.9 & $33 \cdot 3$ \\
\hline Did not respond & 46.9 & $39 \cdot 1$ & $34 \cdot 5$ & $16 \cdot 7$ \\
\hline$\geqslant 10$ Alcoholic beverages a week (\%) & $15 \cdot 6$ & 10.9 & $24 \cdot 1$ & $33 \cdot 3$ \\
\hline No pregnancy after trying $\geqslant 1 \mathrm{y}(\%) \dagger$ & $18 \cdot 5$ & $18 \cdot 6$ & $15 \cdot 4$ & $8 \cdot 3$ \\
\hline Sought fertility consultation $(\%) \dagger$ & $14 \cdot 8$ & $9 \cdot 3$ & $7 \cdot 7$ & $8 \cdot 3$ \\
\hline
\end{tabular}

$\star$ Detection limit $=5 \mu \mathrm{g} / \mathrm{dl}$.

tEver married men. logistic regression. ${ }^{26}$ Covariates were included in the model if the adjusted OR differed from the crude OR by $10 \%$ or more, and if a similar change occurred with other covariates in the model.

Means and covariate adjusted means for the computer assisted sperm analysis motility variables and serum testosterone, $\mathrm{LH}$, and $\mathrm{FSH}$ were compared by analysis of variance and analysis of covariance ${ }^{24}$; adjusted means are presented where appropriate. A least squares regression model was fitted to analyse linear trends. Prevalences of abnormally low testosterone or high $\mathrm{LH}$ and $\mathrm{FSH}$, based on normal laboratory values, are also presented.

\section{Results}

Questionnaires were returned by 929 of the 2469 eligible male employees. Of these 152 donated blood samples, including 119 workers who also provided semen samples. Compared with the non-vasectomised workers who returned the questionnaire, but did not provide semen samples $(n=466)$, semen sample donors were slightly younger and had fewer years of service at the smelter (table 1). Compared with non-donors, fewer semen donors were current smokers or consumed 10 or more alcoholic beverages a week. A greater proportion of the semen sample donors than non-donors reported wanting children in the future and had been unsuccessful in producing a pregnancy after trying for at least one year. The workers who returned questionnaires were quite similar to all currently employed male workers with available work history records $(n=2121)$ for age, mean blood lead concentrations from surveillance in the previous six months, and current work area (table 1). The semen donors, however, were more likely to have participated in the blood lead surveillance in the previous six months than workers with available work histories $(66 \cdot 4 \% v$ $46 \cdot 2 \%)$. The semen donors were younger than

Table 3 Geometric means (SD) of standard variables of semen and arithmetic means SDs of computer assisted sperm analysis measures of motility by current blood lead concentration

\begin{tabular}{|c|c|c|c|c|c|}
\hline & \multicolumn{4}{|c|}{ Blood lead concentration $(\mu g / d l)$} & \multirow[b]{2}{*}{$P$ value } \\
\hline & $<15$ & $15-24$ & $25-39$ & $\geqslant 40$ & \\
\hline Number & 32 & 46 & 29 & 12 & \\
\hline \multicolumn{6}{|l|}{ Standard semen quality: } \\
\hline $\begin{array}{l}\text { Sperm concentration (million cells } / \mathrm{ml}) \dagger \\
\text { (GSD) } \ddagger\end{array}$ & $\begin{array}{r}79 \cdot 1 \\
2 \cdot 7\end{array}$ & $\begin{array}{r}56 \cdot 5 \\
3 \cdot 1\end{array}$ & $\begin{array}{r}62 \cdot 7 \\
2 \cdot 5\end{array}$ & $\begin{array}{r}44 \cdot 4 \\
4 \cdot 8\end{array}$ & $0 \cdot 11$ \\
\hline Total sperm (million cells) $t$ & $186 \cdot 0$ & $153 \cdot 0$ & $137 \cdot 0$ & $89 \cdot 1$ & 0.04 \\
\hline (GSD) $\ddagger$ & $3 \cdot 2$ & $3 \cdot 7$ & $2 \cdot 5$ & $6 \cdot 9$ & \\
\hline $\begin{array}{l}\text { Motile sperm (\%) } \\
\text { (GSD) }\end{array}$ & $\begin{array}{r}45 \cdot \overline{8} \\
1 \cdot 7\end{array}$ & $\begin{array}{r}56 \cdot 4 \\
1 \cdot 3\end{array}$ & $\begin{array}{r}56 \cdot 3 \\
1 \cdot 3\end{array}$ & $\begin{array}{r}36 \cdot 8 \\
3 \cdot 4\end{array}$ & $0 \cdot 16$ \\
\hline Rapid and linear motile sperm (\%) $t$ & $13 \cdot 1$ & $19 \cdot 4$ & $18 \cdot 8$ & $15 \cdot 9$ & 0.97 \\
\hline $\begin{array}{l}\text { (GSD) } \ddagger \\
\text { Strict normal morphology }(\%) \dagger\end{array}$ & $3 \cdot 4$ & $3 \cdot 1$ & $2 \cdot 8$ & 4.9 & \\
\hline $\begin{array}{l}\text { Strict normal morphology }(\%) \dagger \\
\text { (GSD) } \ddagger\end{array}$ & $17 \cdot 7$ & $18 \cdot 4$ & $17 \cdot 3$ & $16 \cdot 2$ & 0.81 \\
\hline \multicolumn{6}{|l|}{ Computer assisted sperm analysis: } \\
\hline $\begin{array}{l}\text { Velocity of the average path }(\mu \mathrm{m} / \mathrm{s}) \S \\
\text { (SD) }\end{array}$ & $\begin{array}{r}70 \cdot 0 \\
2 \cdot 2\end{array}$ & $\begin{array}{r}70 \cdot 3 \\
1 \cdot 8\end{array}$ & $\begin{array}{r}69 \cdot 5 \\
2 \cdot 2\end{array}$ & $\begin{array}{r}70 \cdot 8 \\
3 \cdot 6\end{array}$ & 0.90 \\
\hline Straight line velocity $(\mu \mathrm{m} / \mathrm{s}) \oint$ & $59 \cdot 2$ & $60 \cdot 5$ & 59.7 & $61 \cdot 4$ & 0.67 \\
\hline (SD) & $2 \cdot 2$ & $1 \cdot 8$ & $2 \cdot 3$ & $3 \cdot 7$ & \\
\hline Curvilinear velocity $(\mu \mathrm{m} / \mathrm{s}) \oint$ & $117 \cdot 7$ & $116 \cdot 8$ & $115 \cdot 0$ & $110 \cdot 4$ & 0.34 \\
\hline (SD) & $3 \cdot 3$ & $2 \cdot 7$ & $3 \cdot 3$ & $5 \cdot 4$ & \\
\hline Amplitude of lateral head deflection $(\mu \mathrm{m}) \oint$ & $4 \cdot 7$ & $4 \cdot 6$ & $4 \cdot 5$ & $4 \cdot 0$ & 0.05 \\
\hline (SD) & $0 \cdot 2$ & $0 \cdot 1$ & 0.2 & $0 \cdot 2$ & \\
\hline Linearity $(\%) \circlearrowleft$ & $50 \cdot 2$ & $51 \cdot 8$ & $52 \cdot 0$ & $55 \cdot 0$ & 0.87 \\
\hline (SD) & $1 \cdot 3$ & $1 \cdot 1$ & $1 \cdot 3$ & $2 \cdot 1$ & \\
\hline
\end{tabular}

${ }^{\star}$ From least squares regression model.

tGeometric mean.

$\neq$ GSD = geometric SD.

SAge adjusted mean. 
Table 4 Adjusted ORs for variables of semen quality that were below World Health Organisation normal levels by current blood lead concentration groups

\begin{tabular}{|c|c|c|c|c|}
\hline & \multicolumn{4}{|c|}{ Blood lead concentration ( $\mu g / d l)$} \\
\hline & $<15$ & $15-24$ & $25-39$ & $\geqslant 40$ \\
\hline & Reference & $O R^{*}(95 \% C I)$ & $O R^{*}(95 \% C I)$ & $O R^{*}(95 \% C I)$ \\
\hline \multirow{6}{*}{$\begin{array}{l}\text { Sperm concentration (million cells/ml) } \\
<20 \dagger \\
\text { Total sperm (million cells) } \\
<40 \dagger \\
\text { Strict normal morphology }(\%) \\
<14 \ddagger \\
\text { Motile sperm (\%) } \\
<50 \dagger \\
\text { Rapid linear motile sperm }(\%) \\
<25 \dagger\end{array}$} & 1 & $4 \cdot 3(0 \cdot 8,23 \cdot 3)$ & $2 \cdot 1(0 \cdot 3,14 \cdot 5)$ & $8 \cdot 2(1 \cdot 2,57 \cdot 9)$ \\
\hline & & & & \\
\hline & 1 & $1 \cdot 7(0 \cdot 4,7 \cdot 3)$ & $1 \cdot 0(0 \cdot 2,5 \cdot 6)$ & $2 \cdot 6(0 \cdot 4,15 \cdot 7)$ \\
\hline & 1 & $1.3(0 \cdot 4,4 \cdot 0)$ & $1 \cdot 6(0 \cdot 5,5 \cdot 3)$ & $1 \cdot 6(0 \cdot 3,8 \cdot 4)$ \\
\hline & 1 & $0 \cdot 4(0 \cdot 2,1 \cdot 0)$ & $0.5(0 \cdot 2,1 \cdot 5)$ & $0 \cdot 8(0 \cdot 2,3 \cdot 1)$ \\
\hline & 1 & $0 \cdot 5(0 \cdot 2,1 \cdot 2)$ & $0 \cdot 6(0 \cdot 2,1 \cdot 8)$ & $0.4(0 \cdot 1,1 \cdot 7)$ \\
\hline
\end{tabular}

^Adjusted for age group $(\leqslant 35,36-45, \geqslant 46)$, smoking status (yes, no, missing).

TMinimum normal level as established by the World Health Organisation.

† Mruger strict morphology normal level.

the overall working population and were more likely to work in the smelter or the lead refinery.

The mean blood lead concentration for semen donors from the sample drawn for the study was $22.4 \mu \mathrm{g} / \mathrm{dl}$ with a range of 5 (detection limit) to $58 \mu \mathrm{g} / \mathrm{dl}$. Table 2 shows the distribution of study participants by current blood lead concentration. The mean age was similar among the groups of differing blood lead concentrations, but the highest blood lead concentration group had, on average, more years of service at the smelter, a larger proportion of current smokers, and were more likely to consume 10 or more alcoholic drinks a week. A history of difficulty in producing a pregnancy and having sought medical advice for fertility problems were more common among men with current blood lead concentrations less than $25 \mu \mathrm{g} / \mathrm{dl}$.

The geometric mean sperm concentration and total sperm count were inversely related to current blood lead concentration, with the largest effects detected among men with blood lead concentrations of $40 \mu \mathrm{g} / \mathrm{dl}$ or more (table 3 ). The linear relation between blood lead concentration and sperm count was not altered after covariant adjustment for age, smoking, alcohol use, period of abstinence, and blood concentrations of other metals. Compared with those with current blood lead concentrations of less than $15 \mu \mathrm{g} / \mathrm{dl}$, workers with more than $40 \mu \mathrm{g} / \mathrm{dl}$ had an increased risk of having a below WHO normal sperm concentration (adjusted OR 8.2, 95\% CI $1 \cdot 2-57 \cdot 9)$ and total sperm count (adjusted OR $2 \cdot 6,95 \%$ CI $0 \cdot 4-15 \cdot 7$, table 4 ). Controlling for the effects of alcohol consumption, pres- ence of other metals in the blood, zinc, and cadmium in particular, period of abstinence before sample collection, history of reproductive difficulties, the use of hot tubs and saunas, and history of reproductive tract infection did not decrease the OR point estimates.

The percentage of sperm meeting the strict normal morphology criteria did not vary with blood lead concentration (table 3 ). Only a slightly increased risk of a below normal morphology was found in the group with the highest blood lead concentration (OR 1.6, 95\% CI $0 \cdot 3-8 \cdot 4$, table 4 ).

The estimates of percentage of motile sperm and percentage of rapid and linear sperm showed no consistent associations between increasing lead exposure and poor sperm motility. The mean percentage motile sperm was lowest in the group with $40 \mu \mathrm{g} / \mathrm{dl}$ blood lead concentration; however, there was no trend for mean percentage of rapid and linear motile sperm (table 3). Moreover, the OR for below WHO normal values for these variables were less than 1.0 in the groups exposed to lead (table 4). The lack of association between blood lead concentration and sperm motility was confirmed by the results of the computer assisted sperm analysis for motility (table 3), although the amplitude of lateral head deflection did decrease with increasing blood lead concentrations.

When classified by long term exposure to lead, calculated from the mean blood lead concentrations of the preceding 10 years, 20 , 28,45 , and 26 men had 10 year averages of $<15,15-24,25-39$, and $\geqslant 40 \mu \mathrm{g} / \mathrm{dl}$, respectively. To evaluate the effects of long term lead

Table 5 Geometric mean and geometric SD of selected variables of semen quality by mean blood lead concentration of the preceding 10 years for workers with current blood lead concentration below 40

\begin{tabular}{|c|c|c|c|c|c|}
\hline & \multicolumn{4}{|c|}{ Blood lead concentration $(\mu g / d l)$} & \multirow[b]{2}{*}{ Pvalue* } \\
\hline & $<15$ & $15-24$ & $25-39$ & $\geqslant 40$ & \\
\hline $\begin{array}{l}\text { Number } \\
\text { Mean chronic blood lead concentration }(\mu \mathrm{g} / \mathrm{dl}) \\
\text { Sperm concentration (million cells } / \mathrm{ml} \text { ) }\end{array}$ & $\begin{array}{l}20 \\
10 \cdot 3\end{array}$ & $\begin{array}{l}28 \\
20 \cdot 7\end{array}$ & $\begin{array}{l}44 \\
31 \cdot 5\end{array}$ & $\begin{array}{l}15 \\
47 \cdot 9\end{array}$ & \\
\hline $\begin{array}{l}\text { Geometric mean } \\
\text { (GSD) }\end{array}$ & $\begin{array}{r}72 \cdot 4 \\
2 \cdot 8\end{array}$ & $\begin{array}{r}72 \cdot 0 \\
2 \cdot 8\end{array}$ & $\begin{array}{r}61 \cdot 8 \\
2 \cdot 7\end{array}$ & $\begin{array}{r}49 \cdot 4 \\
3 \cdot 3\end{array}$ & $0 \cdot 29$ \\
\hline $\begin{array}{l}\text { Total sperm (million cells) } \\
\text { Geometric mean } \\
\text { (GSD) }\end{array}$ & $\begin{array}{r}201 \cdot 0 \\
2 \cdot 9\end{array}$ & $\begin{array}{r}188 \cdot 0 \\
3 \cdot 1\end{array}$ & $\begin{array}{r}144 \cdot 0 \\
3 \cdot 3\end{array}$ & $\begin{array}{r}108 \cdot 0 \\
3 \cdot 6\end{array}$ & 0.07 \\
\hline $\begin{array}{l}\text { Strict normal morphology (\%) } \\
\text { Geometric mean } \\
\text { (GSD) }\end{array}$ & $\begin{array}{r}16 \cdot 7 \\
2 \cdot 4\end{array}$ & $\begin{array}{r}19 \cdot 4 \\
2 \cdot 2\end{array}$ & $\begin{array}{r}16 \cdot 8 \\
2 \cdot 4\end{array}$ & $\begin{array}{r}20 \cdot 3 \\
2 \cdot 4\end{array}$ & $0 \cdot 78$ \\
\hline
\end{tabular}

^From least squares regression model. 
Table 6 Mean (SD) and percentage with abnormal clinical concentrations of testosterone, LH, and FSH by current blood lead concentration

\begin{tabular}{|c|c|c|c|c|c|}
\hline & \multicolumn{4}{|c|}{ Blood lead concentration ( $\mu g / d l)$} & \multirow[b]{2}{*}{$P$ value ${ }^{\star}$} \\
\hline & $<15$ & $15-24$ & $25-39$ & $\geqslant 40$ & \\
\hline $\begin{array}{l}\text { Number } \\
\text { Mean blood lead } \mu \mathrm{g} / \mathrm{dl} \\
\text { Testosterone }(\mathrm{nmol} / \mathrm{l})\end{array}$ & $\begin{array}{l}36 \\
10 \cdot 1\end{array}$ & $\begin{array}{l}53 \\
19 \cdot 4\end{array}$ & $\begin{array}{l}41 \\
31 \cdot 0\end{array}$ & $\begin{array}{l}22 \\
45 \cdot 5\end{array}$ & \\
\hline $\begin{array}{l}\text { Mean } \\
\text { SD } \\
<9.7 \mathrm{nmol} / \mathrm{l}(\%) \dagger\end{array}$ & $\begin{array}{r}15 \cdot 5 \\
6 \cdot 2 \\
8 \cdot 3\end{array}$ & $\begin{array}{r}18 \cdot 2 \\
5 \cdot 7 \\
5 \cdot 7\end{array}$ & $\begin{array}{r}16 \cdot 1 \\
6 \cdot 1 \\
9 \cdot 8\end{array}$ & $\begin{array}{r}15 \cdot 2 \\
4 \cdot 5 \\
13 \cdot 6\end{array}$ & 0.49 \\
\hline $\begin{array}{l}\text { Luteinising hormone (IU/l): } \\
\text { Mean } \\
\text { SD } \\
>13.9 \mathrm{IU} / 1(\%)\end{array}$ & $\begin{array}{l}4 \cdot 6 \\
1 \cdot 6 \\
0 \cdot 0\end{array}$ & $\begin{array}{l}4 \cdot 5 \\
1 \cdot 5 \\
0 \cdot 0\end{array}$ & $\begin{array}{l}4 \cdot 2 \\
1 \cdot 1 \\
0 \cdot 0\end{array}$ & $\begin{array}{l}4 \cdot 9 \\
2 \cdot 4 \\
0 \cdot 0\end{array}$ & 0.46 \\
\hline $\begin{array}{l}\text { Follicle stimulating hormone (IU/1): } \\
\text { Mean } \\
\text { SD } \\
>12 \cdot 2 \text { IU } / 1(\%) \ddagger\end{array}$ & $\begin{array}{l}5 \cdot 1 \\
2 \cdot 5 \\
0 \cdot 0\end{array}$ & $\begin{array}{l}5 \cdot 0 \\
2 \cdot 8 \\
1 \cdot 9\end{array}$ & $\begin{array}{l}4 \cdot 4 \\
1 \cdot 6 \\
0 \cdot 0\end{array}$ & $\begin{array}{l}5 \cdot 8 \\
5 \cdot 3 \\
9 \cdot 9\end{array}$ & 0.49 \\
\hline
\end{tabular}

^From least squares regression model.

†Below laboratory normal.

¥Above laboratory normal

exposure independently of current high blood lead concentrations workers with current blood lead concentrations of $40 \mu \mathrm{g} / \mathrm{dl}$ ( $\mathrm{n}=$ 12) were excluded. The prevalence of workers with below normal variables of semen quality was similar across the long term exposure groups. The geometric mean sperm concentration, and total sperm count, however, showed consistent inverse trends with long term blood lead concentration (table 5). Sperm morphology and all measures of sperm motility were not associated with long term lead exposure.

We found minimal differences in mean serum testosterone, $\mathrm{LH}$, and FSH across the concentrations of either current or long term lead exposure (table 6). Controlling for the effects of age, smoking, alcohol, and other metals did not change these findings. Furthermore, these results did not change materially when stratified by total sperm count ( $<40 v \geqslant 40$ million cells/ejaculate).

\section{Discussion}

The inverse associations found between current blood lead concentration and total sperm count and sperm concentration is further evidence that lead exposure has a direct effect on spermatogenesis. The effect was most pronounced among men with current blood lead concentrations over $40 \mu \mathrm{g} / \mathrm{dl}$. Moreover, we found an association between long term lead exposure and a decrease in sperm number that is apparently independent of current lead burden. Neither current nor long term exposure to lead was consistently related to indicators of sperm morphology, sperm motility, or reproductive hormone concentrations.

The interpretation of our results, with reference to previous research, must consider the inherent limitations and potential advantages of this study. Similar to most studies requiring voluntary donation of semen samples, the overall participation rate was low. Fewer than $40 \%$ of the eligible workers returned the questionnaire, and only $21 \%$ of the non-vasectomised men who returned the questionnaire volunteered to donate semen samples. However, workers who returned questionnaires were representative of all eligible subjects for age and blood lead concentrations, and semen donors and study participants who did not donate semen samples had similar demographic and exposure profiles. Semen sample donors were more likely to work in the lead smelter and were thus more often subject to blood lead surveillance.

Cross sectional studies of semen quality can be subject to selection bias if men with histories of reproductive difficulties are overrepresented among semen sample donors, especially if self selection is related to exposure level. In this study the self reported prevalence of periods of subfertility was somewhat higher among the semen donors than other nonvasectomised workers. The excess of subfertility, however, was limited to men with current blood lead concentrations below $25 \mu \mathrm{g} / \mathrm{dl}$. Thus, a selection bias based on self perceived infertility would most likely result in underestimates of the true associations between lead exposure and semen quality.

Logistical considerations of this cross sectional study permitted the collection of only one semen and one blood sample from each participant. The validity of a semen analysis improves when repeated samples are taken, although a single measurement is generally adequate to characterise reliably the lowest and highest tails of the distributions. ${ }^{27}$ The pulsatile release of testosterone, $\mathrm{LH}$, and FSH requires sequential sampling over a period of several hours for diagnostic assessment in an individual man. Nevertheless, a single sample, preferably drawn at the same time of day, is considered adequate to detect a population shift in cross sectional studies. ${ }^{28}$ The samples drawn for semen donors were drawn in the morning, usually between 6 and $8 \mathrm{am}$. The samples for the other blood donors were scattered throughout the day. Nevertheless, the results of the hormone analysis were essentially the same when limited to semen donors.

A notable advantage of this study is the relative stability of the workforce and the availability of historical employment and blood lead monitoring data. Work history and blood lead data permitted comparisons of participants and non-participants and an evaluation of the effects of long term exposure on variables of semen quality, which until now has not been reported. Measurement of other metals allowed control of potential confounding from other reproductive toxicants that might be encountered in the same environment.

This study provides further evidence that spermatogenesis may be impaired when blood lead concentrations exceed $40 \mu \mathrm{g} / \mathrm{dl}$. Of particular interest was the increased risk of below normal sperm concentrations and counts which were related to subfertility. ${ }^{19}$ Similar results have been reported by Lancrajan et $a l,{ }^{8}$ who found an increase in the prevalence of altered spermatogenesis related to exposure among battery factory workers with group mean blood lead concentrations from 41-75 $\mu \mathrm{g} / \mathrm{dl}$. Studies of other populations of men exposed to higher lead concentrations than in our study have consistently reported similar adverse effects on spermatogenesis. ${ }^{9-10}$ Conversely, a study of battery factory workers 
in Sweden reported no differences in variables of semen quality between workers with mean lead concentrations of $45 \mu \mathrm{g} / \mathrm{dl}$ and $22 \mu \mathrm{g} / \mathrm{dl}$. $^{11}$

Independent of current blood lead concentrations, sperm count and concentration were lower among workers with long term increases in blood lead concentrations. This finding may indicate that recovery from the effects of recent lead exposure is not rapid or that men with historically high blood lead concentrations may be more susceptible to lower exposures. The few workers with current high exposures and the high correlation between current and long term lead concentrations, however, did not allow for the separation of effects from these exposures.

In contrast to previous research, ${ }^{810}$ we found no relation between lead exposure and sperm morphology and motility. It is noteworthy, however, that in the studies reporting an association between lead exposure and sperm motility and morphology, the blood lead concentrations of the lowest exposure groups were similar to those of the highest exposure group in this study.

Moderate increases in serum FSH and $\mathrm{LH}^{1718}$ and decreased serum testosterone ${ }^{17}$ have been attributed, albeit inconsistently, ${ }^{16}$ to occupational exposure to lead. A low serum testosterone or increases in the concentrations of the gonadotropins would indicate a hormonal mechanism for the suppression of sperm production found. The lack of such an association implies that lead directly affects testicular function.

The results of this study show that measurable impairment of spermatogenesis is associated with current and long term blood lead concentrations below those requiring a man to leave work for medical reasons, as specified by the United States Occupational Safety and Health Administration. ${ }^{3}$ Assessment of the ultimate consequences of moderate lead concentrations $(25-50 \mu \mathrm{g} / \mathrm{dl})$ on fertility and perinatal outcomes will require in depth follow up studies of cohorts with occupational and environmental exposures in that range.

We are grateful to the membership of United Steel Workers Locals 480 and 9705 and to Cominco Metals for supportin this study and for providing a great deal of assistance. Special thanks are also due to Tom Wynn, Peter Fulcher, and Graham Kenyon for help with the organisation of the study, and to ind Coxall for We also thank Jesara Schroeder and Genna Ratiu for their assistance in the field laboratory, Karin Yeatts for compiling assistance in the field laboratory, Karin Yeatts for compiling
historical blood lead monitoring data, and Iris Nielsen and Changpu Yu for sperm morphology assessments and laboratory coordination. This research was sponsored by United States
National Institutes of Health Grant ES04696, United States National Institutes of Health Grant ES04696, United States R03-OH02966, and the British Columbia Workers' Compensation Board. BHA was supported by NIEHS Training Gran T32-ES07262. Hormone analyses were performed in the laboratory of Dr William J Bremner with support from National Institutes of Health Population Center Grant P50-HD12629.

1 Agency for Toxic Substances and Disease Registry (ATSDR). Toxicological profile for lead. Washington: US
Department of Health and Human Services, US Government Printing Office, 1990.

2 Lockitch G. Perspectives on lead toxicity. Clin Biochem 1993;26:371-81.

3 Office of the Federal Register. Code of federal regulations: occupational safety and health standards. Sub-part Z: toxic and hazardous substances-lead. Washington, DC: Office of the Federal Register, National Archives and Records Administration, 1985. (29 CFR 1910·1025.)

4 Centers for Disease Control. Surveillance for occupational lead exposure-United States, 1987. Morbidity and Mortality Weekly Report 1989;38:687-94.

5 Winder C. Reproductive and chromosomal effects of occupational exposure to lead in the male. Reprod Toxico 1989;3:221-33.

6 US Congress, Office of Technology Assessment. Reproductive health hazards in the workplace. Washington: Reproductive health hazards in the workplace. Washington

7 Cullen MR, Kayne RD, Robins JM. Endocrine and reproductive dysfunction in men associated with occupational inorganic lead intoxication. Arch Environ Health 1984 39:421-40.

8 Lancranjan I, Popescu HI, Gavenesu O, Klapsh I, Serbanescu M. Reproductive ability of workmen occupationally exposed to lead. Arch Environ Health 1975;30: 396-401.

9 Assennato G, Claudio P, Molinini R, Candela RG, Baser ME, Altamura BM, Giorgino, R. Sperm count suppression without endocrine dysfunction in lead-exposed men. Arch Environ Health 1986;41:387-90.

10 Lerda D. Study of sperm characteristics in persons occupationally exposed to lead. Am $\mathcal{f}$ Ind Med 1992;22:567-71.

11 Wildt K, Eliasson R, Berlin M. Effects of occupationa exposure to lead on sperm and semen. In: Clarkson TW, Nordberg GF, Sager PR, eds. Reproductive and developmental toxicity of metals. New York: Plenum Press, 1983.

12 Lindbohm MJ, Sallemen M, Anttila A, Taskinen $H$, Hemminki K. Paternal occupational lead exposure and spontaneous abortion. Scand $\mathcal{f}$ Work Environ Health 1991;17:95-103.

13 Nordstrom S, Beckman L, Nordenson I. Occupational and environmental risks in and around a smelter in northern Sweden. V: spontaneous abortion among female employees and decreased birth weight in their offspring. ees and decreased birth
Hereditas 1979;90:291-6.

14 Beckman L, Nordstrom S. Occupational and environmental risks in and around a smelter in northern Sweden. IX fetal mortality among wives of smelter workers. Hereditas 1982;97:1-7.

15 Gennart JP, Buchet JP, Roels H, Ghyselen P, Ceulemans E, Lauwerys R. Fertility of male workers exposed to cadmium, lead or manganese. Am $\mathcal{f}$ Epidemiol 1992;135: 1208-19.

16 Gustafson A, Hedner P, Schütz A, Skerfving S Occupational lead exposure and pituitary function. In Occupational lead exposure and pituitary
Arch Occup Environ Health 1989;61:277-81.

17 Rodamilans M, Osaba MJM, To-Figueras J, Rivera F Marques M, Pérez $P$, Corbella J. Lead toxicity on endocrine testicular function in an occupationally exposed population. Human Toxicol 1988;7:125-8.

$18 \mathrm{Ng} \mathrm{TP}$, Goh HH, Ng YL, Ong HY, Ong CN, Chia KS, al. Male endocrine functions in workers with moderate exposure to lead. $\mathrm{Br} \mathcal{F}$ Ind Med 1991;48:485-91.

19 World Health Organization. WHO laboratory manual for the examination of human semen and semen-cervical mucus interaction. Cambridge: Cambridge University Press, 1992.

20 Kruger TF, Menkveld R, Stander FSH, Lombard CJ, Van der Merwe JP, van Zyl JA, Smith K. Sperm morphologic features as a prognostic factor in in-vitro fertilization. Fertil Steril 1986;46:118-23.

21 Boyers SP, Katz DF, Davis RO. Automatic semen analysis. Current Problems in Obstetrics, Gynecology and Fertility 1989;12:165-200.

22 Henry JB. Clinical diagnosis and management by laboratory methods, 16th ed. Philadelphia: WB Saunders, 1979: 513-5.

23 Matsumoto AM, Paulsen CA, Hopper BR, Reber RW, Bremner WH. Human chorionic gonadotropin and testicular function: stimulation of testosterone, testosterone precursors, and sperm production despite high $\mathrm{E}_{2}$ levels. $f$ precursors, and sperm production despite
Clin Endocrinol Metab 1983;56:720 -

24 Fisher LD, van Belle G. Biostatistics. A methodology for the health sciences. New York: John Wiley, 1993

25 Rothman KJ. Modern epidemiology. Boston: Little-Brown, 1986.

26 Breslow NE, Day NE. Statistical methods in cancer research. Vol 1. The analysis of case-control studies. Lyon, France: International Agency for Research on Cancer, 1980.

27 Schrader SM, Turner TW, Breitenstein MJ, Simon SD. Longitudinal study of semen quality of unexposed workers I: study overview. Reprod Toxicol 1988;2:183-90.

28 Schrader SM, Turner TW, Breitenstein MJ, Simon SD. Measuring male reproductive hormones for occupational field studies. F Occup Med 1993;35:574-6. 